\title{
PENGGUNAAN GARAM AMMONIUM DALAM PRODUKSI KARET VISKOSITAS RENDAH DARI LATEKS
}

\author{
The Use of Ammonium Salt on the Production of Low Viscosity Rubber from Latex
}

\author{
Afrizal VACHLEPI dan Didin SUWARDIN
}

Balai Penelitian Sembawa - Pusat Penelitian Karet

J1. Raya Palembang-Betung Km.29 Kotak Pos 1127 Palembang

Sumatera Selatan 30001

Email : A_Vachlepi@yahoo.com

Diterima : 28 Juli 2015 / Direvisi : 31 Agustus 2015 / Disetujui : 27 September 2015

\begin{abstract}
Indonesia's natural rubber exports are still dominated by SIR 20 that is used as a raw material for tyre production. To reduce energy consumption, most tyre manufacturers have started substituting rubber SIR 20 with more suitable quality such as constant viscosity and low viscosity rubber. Both types of rubber are able to reduce energy consumption. The addition of additives is required to produce a low viscosity rubber. The aims of this study was to identify and to search for the best of additive from the ammonium salt groups which could be used in the production of low viscosity rubber in accordance with the quality requirements of export. This research used a completely randomized design (CRD) with one treatment factor, namely the type of additives consisting of ammonium sulphate, ammonium chloride, ammonium dihydrogen phosphate, ammonium nitrate and HNS as a control with a dose of $0.15 \%$ weight by weight $(w / w)$ dry rubber and without additives (blank). Parameters observed consisting of coagulating conditions ( $\mathrm{pH}$ and time), Po, PRI, ASHT, Mooney viscosity, SVI, ash content and gel content. The results showed that only two types of ammonium salt compound which could be used as an additive to produce a low viscosity rubber, namely ammonium sulphate and ammonium dihydrogen phosphate. The quality both of the rubber met the requirements as a low viscosity rubber in accordance with SNI No. 1903:2011 of the SIR.
\end{abstract}

Keywords: Additives, natural rubber, quality, low viscosity

\section{Abstrak}

Ekspor karet alam Indonesia masih didominasi SIR 20 yang digunakan sebagai bahan baku produksi ban. Untuk mengurangi konsumsi energi, sebagian pabrik ban sudah mulai mensubstitusi karet SIR 20 dengan jenis mutu yang lebih sesuai berupa karet viskositas mantap dan viskositas rendah. Kedua jenis karet alam ini mampu mengurangi konsumsi energi. Penambahan aditif diperlukan untuk memproduksi karet viskositas rendah. Penelitian ini bertujuan untuk mengetahui dan mencari aditif terbaik dari kelompok senyawa garam ammonium yang dapat digunakan dalam pembuatan karet alam viskositas rendah sesuai dengan persyaratan mutu ekspor. Penelitian ini menggunakan rancangan acak lengkap (RAL) dengan satu faktor perlakuan, yaitu jenis bahan aditif terdiri dari ammonium sulfat, ammonium klorida, ammonium dihidrogen fosfat dan ammonium nitrat serta HNS sebagai kontrol dengan dosis $0,15 \%$ berat per berat $(\mathrm{b} / \mathrm{b})$ karet kering dan tanpa aditif (blanko). Parameter yang diamati terdiri atas kondisi penggumpalan $(\mathrm{pH}$ dan waktu penggumpalan), Po, PRI, ASHT, viskositas Mooney, SVI, kadar abu dan kadar gel. Hasil penelitian menunjukkan bahwa hanya dua jenis senyawa garam ammonium yang dapat digunakan sebagai aditif untuk menghasilkan karet viskositas rendah yaitu ammonium sulfat dan ammonium dihidrogen fosfat. Mutu kedua karet tersebut memenuhi persyaratan sebagai karet viskositas rendah sesuai dengan SNI No. 1903-2011 tentang SIR.

Kata kunci: Aditif, karet alam, mutu, viskositas rendah

\section{PENDAHULUAN}

Dengan semakin meningkatnya kebutuhan energi dan kemajuan teknologi, sebagian industri ban saat ini sudah mulai mensubstitusi karet SIR 20 dengan jenis mutu yang lebih baik berupa karet viskositas mantap (constant viscosity/CV) dan viskositas rendah (low viscosity/LoV). Kedua jenis karet alam ini mampu memberikan keuntungan karena dapat mengurangi konsumsi energi. Penggunaan karet LoV dalam industri pembuatan ban dapat mengurangi proses mastikasi. Alam (2008) 
menyatakan bahwa proses mastikasi merupakan proses pelunakan (plastisasi) elastomer karet alam sebagai langkah persiapan bagi proses pencampuran dengan tujuan agar bahan kimia yang ditambahkan dapat tercampur merata. Proses mastikasi ini mengkonsumsi energi yang cukup besar dan mungkin sangat mahal (Daik et al., 2007). Energi yang dibutuhkan untuk proses ini menggunakan sekitar $33-35 \%$ dari total energi pada saat pembuatan kompon (Solichin dan Immanuel, 1991). Dengan berkurangnya proses mastikasi, konsumsi energi juga menjadi lebih rendah sehingga lebih efisien dan mengurangi biaya produksi.

Selain itu, produksi karet SIR 20 umumnya menggunakan bahan olah karet (bokar) dari petani. Bokar petani ini cenderung mempunyai mutu yang belum baik karena menggunakan bahan penggumpal tidak anjuran dan bahkan ada diantaranya ditambahkan kotoran berupa tatal (kulit pohon karet sisa penyadapan). Agar produk karet remah yang menggunakan bahan baku berasal dari bokar petani memenuhi persyaratan ekspor sesuai SNI No. 1903-2011 tentang SIR, maka perlu tahapan proses pengolahan yang cukup panjang. Akibatnya karet alam SIR 20 yang diekspor Indonesia mempunyai nilai viskositas Mooney yang cukup tinggi. Karet alam dengan nilai viskositas yang tinggi kurang disukai pabrik ban karena memerlukan proses mastikasi untuk proses pelunakannya.

Untuk menurunkan nilai viskositas karet alam sesuai persyaratan mutu dan kebutuhan pabrik ban dapat dilakukan dengan penambahan bahan aditif. Penambahan aditif dari kelompok senyawa garam ammonium diduga mampu menurunkan viskositas Mooney karet alam sehingga menghasilkan karet jenis mutu LoV. Beberapa senyawa yang tergolong dalam kelompok garam ammonium antara lain ammonium sulfat, ammonium asetat, dan ammonium nitrat. Penelitian mengenai aplikasi penggunaan aditif untuk menurunkan nilai viskositas karet alam belum banyak dilakukan. Hal ini disebabkan oleh masih sedikitnya permintaan karet LoV dari pabrik ban. Penggunaan karet LoV diperkirakan akan terus meningkat seiring dengan semakin pedulinya pabrik ban dalam meningkatkan efisiensi kegiatan produksi kaitannya dengan penggunaan energi.

Penelitian ini bertujuan untuk mengetahui dan mencari aditif terbaik dari kelompok senyawa garam ammonium yang dapat digunakan dalam pembuatan karet alam LoV sesuai dengan persyaratan mutu ekspor.

\section{BAHAN DAN METODE}

Kegiatan penelitian ini dilakukan di Laboratorium Teknologi Pengolahan Balai Penelitian Sembawa, Pusat Penelitian Karet selama bulan Juni-Desember 2014. Bahan yang digunakan terdiri atas lateks kebun yang diperoleh dari kebun riset Balai Penelitian Sembawa, garam ammonium, HNS, asam format (asam semut), $\mathrm{P}_{2} \mathrm{O}_{5}$, kertas lakmus, toluena dan aseton. Alat yang digunakan berupa bak penggumpal, mesin creper, oven, plastimeter, Mooney viskometer, muffle furnace dan gilingan terbuka (open mill).

Penelitian ini menggunakan rancangan acak lengkap (RAL) dengan satu faktor perlakuan, yaitu jenis bahan aditif dengan masing-masing perlakuan diulang sebanyak 3 kali. Jenis bahan aditif yang digunakan untuk menghasilkan karet SIR LoV adalah ammonium sulfat, ammonium klorida, ammonium dihidrogen fosfat dan ammonium nitrat. Sebagai kontrol digunakan aditif berupa HNS dan juga tanpa aditif (blanko). Pada penelitian ini dosis penggunaan bahan aditif garam ammonium mengikuti dosis standar penggunaan HNS yaitu $0,15 \%$ berat per berat $(b / b)$ karet kering.

Parameter yang diamati terdiri atas kondisi penggumpalan ( $\mathrm{pH}$ dan waktu penggumpalan), nilai plastisitas awal (Po), indeks ketahanan plastisitas (plasticity retention index/PRI), pengujian kekerasan selama penyimpanan (accelerated storage hardening test/ASHT), viskositas Mooney, indeks kestabilan viskositas (stability viscosity index/SVI), kadar abu dan kadar gel. Data hasil pengamatan dianalisis secara statistik dan dideskripsikan sesuai persyaratan mutu yang tercantum dalam SNI No. 1903-2011 tentang Standard Indonesian Rubber (SIR) seperti terlihat pada Tabel 1. 
Tabel 1. Persyaratan mutu SNI No.1903: 2011 tentang SIR.

Table 1. Quality requirements SNI No. $1903: 2011$ of SIR.

\begin{tabular}{|c|c|c|c|}
\hline \multirow{2}{*}{$\begin{array}{l}\text { Jenis uji / Karakteristik } \\
\text { Test types / Characteristics }\end{array}$} & \multirow{2}{*}{$\begin{array}{l}\text { Satuan } \\
\text { Unit }\end{array}$} & \multicolumn{2}{|c|}{$\begin{array}{c}\text { Spesifikasi } \\
\text { Spesifications }\end{array}$} \\
\hline & & SIR LoV*) & SIR $20 \mathrm{CV}^{* *}$ \\
\hline $\begin{array}{l}\text { Kadar kotoran }(\mathrm{b} / \mathrm{b}), \text { maks } \\
\text { Dirt content }(w / w), \max \end{array}$ & $\%$ & 0,02 & 0,16 \\
\hline $\begin{array}{l}\text { Kadar abu }(\mathrm{b} / \mathrm{b}), \text { maks } \\
\text { Ash content }(w / w), \text { max }\end{array}$ & $\%$ & 0,50 & 1,00 \\
\hline $\begin{array}{l}\text { Kadar zat menguap }(\mathrm{b} / \mathrm{b}) \text {, maks } \\
\text { Volatile matter content }(w / w), \text { max }\end{array}$ & $\%$ & 0,80 & 0,80 \\
\hline $\begin{array}{l}\text { PRI, min } \\
P R I, \min \end{array}$ & - & - & 40 \\
\hline $\begin{array}{l}\text { Po, min } \\
\text { Po, } \min \end{array}$ & - & - & - \\
\hline $\begin{array}{l}\text { Kadar nitrogen }(\mathrm{b} / \mathrm{b}), \text { maks } \\
\text { Nitrogen content }(w / w), \text { max }\end{array}$ & $\%$ & 0,30 & 0,60 \\
\hline $\begin{array}{l}\text { Viskositas Mooney, ML }(1+4) 100^{\circ} \mathrm{C} \\
\text { Mooney viscosity, ML }(1+4) 100^{\circ} \mathrm{C}\end{array}$ & - & $55 \pm 10$ & $60^{+7}-5$ \\
\hline $\begin{array}{l}\text { Warna Lovibond, maks } \\
\text { Lovibond colour, } \text { max }\end{array}$ & $\begin{array}{l}\text { indeks } \\
\text { index }\end{array}$ & - & - \\
\hline $\begin{array}{l}\text { Kadar gel, maks } \\
\text { Gel content, max }\end{array}$ & $\%$ & 4 & - \\
\hline
\end{tabular}

${ }^{2} \mathrm{LoV}=$ Low viscosity

${ }^{* *} \mathrm{CV}=$ Constant viscosity

Sumber (source) : Badan Standarisasi Nasional (2011)

Karet LoV pada penelitian ini dibuat dari lateks kebun (lateks segar). Sebelum dicampurkan ke dalam lateks, bahan aditif terlebih dahulu dibuat menjadi larutan 25\% dengan dosis $0,15 \% \mathrm{~b} / \mathrm{b}$ karet kering. Untuk menentukan dosis penggunaan bahan aditif dalam bentuk larutan 25\%, lateks kebun selanjutnya diukur kadar karet keringnya menggunakan metode hidrometri. Selanjutnya lateks masing-masing perlakuan digumpalkan menggunakan larutan asam format $2 \%$ dengan dosis $60 \mathrm{ml}$ per liter lateks. Waktu dan pH penggumpalan setiap perlakuan diamati dan dicatat. Lateks yang sudah menggumpal disimpan selama 24 jam. Tahap berikutnya proses penggilingan koagulum lateks menjadi blankoet menggunakan mesin creper. Blankoet selanjutnya dikeringkan dalam oven bersuhu $110^{\circ} \mathrm{C}$ selama 3-4 jam. Terakhir karet LoV yang sudah kering dianalisa mutunya sesuai parameter pengamatan.

\section{HASIL DAN PEMBAHASAN}

\section{Kondisi Penggumpalan}

Perlakuan bahan aditif tidak berpengaruh terhadap waktu dan $\mathrm{pH}$ penggumpalan lateks (Tabel 2). Hasil ini menunjukkan bahwa penggunaan garam ammonium pada lateks dalam pembuatan karet viskositas rendah (LoV) tidak berbeda dengan perlakuan tanpa penambahan aditif (blanko). Waktu penggumpalan lateks yang ditambahkan bahan aditif garam ammonium sekitar 9-10 menit. Sedangkan waktu penggumpalan lateks untuk perlakuan kontrol (HNS dan blanko/tanpa aditif) hanya 11 menit. Penggunaan aditif garam ammonium juga tidak berpengaruh terhadap $\mathrm{pH}$ penggumpalan lateks karet alam. Secara umum, pH penggumpalan lateks dengan berbagai perlakuan sekitar 4,7-5,0. 
Dalam proses penggumpalan lateks karet alam, bahan koagulan umumnya memiliki peran yang paling besar dalam menentukan waktu dan $\mathrm{pH}$ penggumpalan lateks karet alam. Hal ini terjadi karena porsi penggunaan koagulan lebih besar dibandingkan bahan aditif untuk karet LoV.
Pada penelitian ini bahan koagulan yang digunakan sama, yaitu asam format $2 \%$ dengan dosis sekitar $60 \mathrm{ml}$ per liter lateks. Sedangkan penggunaan aditif garam ammonium relatif kecil hanya $0,15 \% \mathrm{~b} / \mathrm{b}$ karet kering.

Tabel 2. Waktu dan $\mathrm{pH}$ penggumpalan lateks dengan berbagai perlakuan Table 2. Time and $\mathrm{pH}$ of latex coagulation with various treatments

\begin{tabular}{lcc}
\hline \multicolumn{1}{c}{$\begin{array}{c}\text { Jenis bahan aditif } \\
\text { Additive type }\end{array}$} & \multicolumn{2}{c}{$\begin{array}{c}\text { Kondisi Penggumpalan } \\
\text { Coagulation condition }\end{array}$} \\
\cline { 2 - 3 } & $\begin{array}{c}\text { Waktu (menit) } \\
\text { Time (minute) }\end{array}$ & $\mathrm{pH}$ \\
\hline $\begin{array}{l}\text { Ammonium sulfat } \\
\text { Ammonium sulphate }\end{array}$ & 10 & 4,7 \\
$\begin{array}{l}\text { Ammonium klorida } \\
\text { Ammonium chloride }\end{array}$ & 10 & 4,7 \\
$\begin{array}{l}\text { Ammonium asetat } \\
\text { Ammonium acetate }\end{array}$ & 9 & 5,0 \\
Ammonium dihidrogen fosfat & & 5,0 \\
$\begin{array}{l}\text { Ammonium dihydrogen phosphate } \\
\text { Ammonium nitrat }\end{array}$ & 10 & 4,7 \\
$\begin{array}{l}\text { Ammonium nitrate } \\
\text { HNS }\end{array}$ & 9 & 4,7 \\
$\begin{array}{l}\text { HNS } \\
\text { Blanko }\end{array}$ & 11 & 4,7 \\
\hline
\end{tabular}

\section{Plastisitas}

Plastisitas awal (Po) dan PRI karet viskositas rendah (LoV) dari berbagai perlakuan dapat dilihat pada Tabel 3 . Penggunaan bahan aditif garam ammonium sebagai aditif karet alam berpengaruh sangat nyata terhadap mutu plastisitas awal. Nilai Po karet yang menggunakan aditif garam ammonium sekitar 32-35. Angka ini secara umum lebih tinggi dibandingkan HNS dan lebih rendah dari karet tanpa aditif (blanko). Nilai Po karet LoV perlakuan kontrol berturut-turut 25 dan 36.

Tingginya nilai Po dari karet LoV menggunakan aditif garam ammonium diduga terjadi karena terbentuknya mikrogel, yaitu ikatan di dalam individu partikel karet (intra particle crosslink). Dari mikrogel tersebut akan terjadi ikatan silang lebih lanjut yang disebut makrogel. Nilai Po karet alam sebagian dipengaruhi oleh pembentukan mikrogel dan makrogel (Solichin dan Setiadi, 1992). Kondisi ini berbeda dengan aditif HNS dimana karet alam yang dihasilkan mempunyai nilai Po yang rendah. Solichin dan Setiadi (1992) juga menyatakan bahwa pemberian HNS secara nyata menurunkan nilai Po dibandingkan dengan tanpa HNS.

Parameter mutu plastisitas awal tidak menjadi persyaratan mutu yang tercantum dalam SNI No.1903-2011 untuk karet LoV. Tetapi nilai Po yang umumnya lebih disukai konsumen dalam hal ini pabrik ban umumnya lebih dari 30. Hal ini sesuai dengan persyaratan mutu karet ekspor Indonesia yang paling rendah adalah SIR 20 dimana syarat nilai Po minimal 30. Dengan demikian berarti nilai Po karet LoV dengan aditif berupa garam ammonium memenuhi permintaan pabrik ban. 
Tabel 3. Plastisitas awal (Po) dan PRI karet viskositas rendah dengan berbagai perlakuan Table 3. Initial plasticity $(P O)$ and PRI of low viscosity rubber with various treatments

\begin{tabular}{|c|c|c|}
\hline \multirow{2}{*}{$\begin{array}{c}\text { Jenis bahan aditif } \\
\text { Additive type }\end{array}$} & \multicolumn{2}{|c|}{$\begin{array}{l}\text { Parameter mutu } \\
\text { Quality parameters }\end{array}$} \\
\hline & $\begin{array}{l}\text { Po } \\
\text { Po }\end{array}$ & $\begin{array}{l}\text { PRI } \\
\text { PRI }\end{array}$ \\
\hline $\begin{array}{l}\text { Ammonium sulfat } \\
\text { Ammonium sulphate }\end{array}$ & $34 \mathrm{bc}$ & $86 a$ \\
\hline Ammonium klorida & $32 \mathrm{~b}$ & $80 \mathrm{a}$ \\
\hline Ammonium asetat & $35 \mathrm{c}$ & $84 \mathrm{a}$ \\
\hline $\begin{array}{l}\text { Ammonium dihidrogen fosfat } \\
\text { Ammonium dihudrogen phosphate }\end{array}$ & $32 \mathrm{~b}$ & $83 \mathrm{a}$ \\
\hline $\begin{array}{l}\text { Ammonium nitrat } \\
\text { Ammonium nitrate }\end{array}$ & $32 \mathrm{~b}$ & $86 \mathrm{a}$ \\
\hline HNS & $25 \mathrm{a}$ & 85 a \\
\hline $\begin{array}{l}\text { Blanko } \\
\text { Blank }\end{array}$ & $36 c$ & 89 a \\
\hline \multicolumn{3}{|c|}{$\begin{array}{l}\text { Keterangan : } \begin{array}{l}\text { Angka yang diikuti huruf yang sama pada kolom dan baris yang sama, } \\
\text { menunjukkan tidak berbeda nyata pada tingkat signifikasi } 5 \% \text { menurut uji jarak } \\
\text { berganda Duncan }\end{array} \\
\text { Note } \quad \text { Number followed by the same letter on the same line were not significantly with }\end{array}$} \\
\hline \multicolumn{3}{|c|}{$\begin{array}{l}\text { Note } \quad \begin{array}{l}\text { Number followed by the same letter on the same line were not significantly with } \\
\text { Duncan multiple range test at } 5 \%\end{array}\end{array}$} \\
\hline
\end{tabular}

Hasil analisis menunjukkan bahwa penggunaan aditif garam ammonium tidak berpengaruh terhadap nilai indeks ketahanan plastisitas (plasticity retention index/PRI) (Tabel 3). Nilai PRI terendah (80) dihasilkan karet LoV yang menggunakan aditif berupa ammonium klorida dan nilai tertinggi (89) dari karet tanpa penambahan aditif. Dalam SNI No.1903-2011 tentang SIR, parameter mutu berupa PRI juga tidak menjadi salah satu persyaratan untuk jenis karet LoV.

Nilai PRI karet LoV yang ditambahkan bahan aditif garam ammonium sekitar 80-86. Angka ini menunjukkan bahwa karet LoV yang ditambahkan aditif garam ammonium tahan terhadap degradasi oleh oksidasi pada suhu tinggi. Pengujian PRI ini merupakan cara yang sederhana dan cepat untuk mengetahui ketahanan karet mentah dalam hal karet LoV terhadap degradasi oleh oksidasi pada suhu tinggi. Nilai PRI yang tinggi menunjukkan bahwa karet alam tahan terhadap suhu tinggi. Faktor utama yang mempengaruhi nilai PRI adalah pertimbangan antara prooksidan dan antioksidan dalam karet (Solichin, 1991).

\section{ASHT}

Hasil analisis pengujian accelerated storage hardening test (ASHT) disajikan pada Gambar 1. Pengerasan selama penyimpanan merupakan kecenderungan meningkatnya viskositas karet alam selama penyimpanan. Proses ini terjadi karena terbentuknya ikatan silang antar molekul karet yang disebabkan oleh reaksi kondensasi gugus aldehida yang terdapat secara alami dalam molekul karet dan kemungkinan adanya sejumlah kecil gugus peroksida di dalam karet (Abednego, 1981). Reaksi ikatan ini terjadi secara alami yang ditandai dengan kenaikan nilai viskositas Mooney (Solichin, 1995).

Berdasarkan Gambar 1 diketahui bahwa penggunaan aditif berpengaruh terhadap nilai ASHT karet LoV yang dihasilkan. Penggunaan garam ammonium sebagai aditif untuk menghasilkan karet LoV ternyata hanya berbeda dengan perlakuan HNS dan tidak berbeda nyata dengan karet yang tidak ditambahkan aditif (blanko). Hasil ini menunjukkan bahwa nilai ASHT karet LoV dengan aditif berupa garam ammonium cenderung sama dengan karet tanpa aditif (blanko). Nilai ASHT karet LoV berbahan aditif garam ammonium sekitar 22-31. 


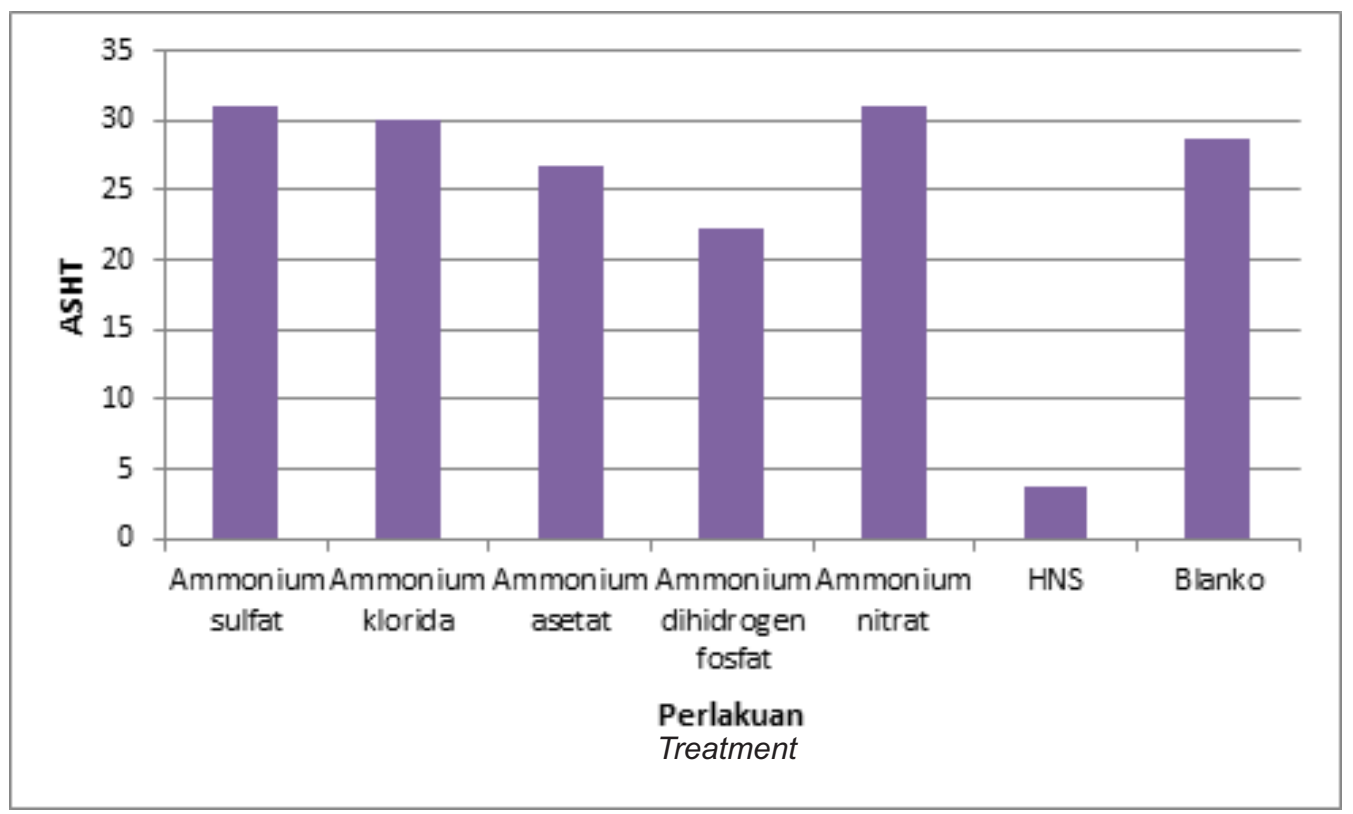

Gambar 1. Nilai ASHT karet viskositas rendah pada berbagai perlakuan Figure 1. ASHT value of low viscosity rubber at various treatments

Perlakuan ammonium dihidrogen fosfat memberikan nilai ASHT yang paling rendah dibandingkan garam ammonium lainnya. Nilai ASHT yang rendah menunjukkan bahwa viskositas karet alam tidak mengalami perubahan (mantap) selama penyimpanan. Dengan demikian aditif ammonium dihidrogen fosfat mampu menghasilkan karet LoV paling baik karena kemungkinan mengalami perubahan selama penyimpanan paling kecil. Parameter ASHT ini juga tidak menjadi persyaratan mutu yang tercantum pada SNI No.19032011 untuk karet viskositas rendah (LoV).

\section{Viskositas Mooney}

Nilai viskositas Mooney dan SVI karet viskositas rendah (LoV) dengan berbagai perlakuan ditampilkan pada Tabel 4. Hasil analisis statistik menunjukkan bahwa penggunaan garam ammonium dalam pembuatan karet LoV tidak berpengaruh nyata terhadap nilai viskositas Mooney dan stability viscosity index (SVI). Walaupun nilai viskositas Mooney berbagai perlakuan tidak berbeda nyata tetapi hanya beberapa aditif yang mampu menghasilkan karet yang memenuhi standar mutu sebagai karet LoV.

Berdasarkan Tabel 4 diketahui bahwa nilai viskositas Mooney karet LoV menggunakan aditif garam ammonium berkisar antara 64-69. Seperti yang tercantum pada SNI No.1903-2011 (Tabel 1) persyaratan mutu untuk karet alam dengan jenis mutu LoV mempunyai nilai viskositas Mooney antara 45-65. Dengan demikian berarti hanya aditif ammonium sulfat dan ammonium dihidrogen fosfat yang mampu menghasilkan karet LoV. Parameter viskositas mooney menggambarkan panjang rantai molekul karet. Semakin tinggi nilai viskositas Mooney semakin panjang rantai molekul karet alam.

Viskositas karet memegang peranan penting dalam proses pencampuran ketika pembuatan kompon, baik untuk tingkat dispersi bahan-bahan kimia kompon di dalam karet maupun tenaga yang diperlukan untuk penggilingan pada mesin pencampur. Viskositas yang terlalu tinggi menyebabkan tingginya konsumsi daya mesin pemroses. Sebaliknya jika viskositasnya sangat rendah, menyebabkan rendahnya gaya geser pada pencampuran yang berakibat material cenderung beraglomerasi maka homogenitasnya rendah (Maspanger, 2008). Karet alam yang memiliki nilai viskositas yang rendah seperti karet LoV lebih mudah dalam proses pencampuran dengan bahan aditif lainnya. Proses pencampuran yang mudah ini dapat 
Tabel 4. Viskositas Mooney dan SVI dari karet viskositas rendah berbagai perlakuan Table 4. Mooney viscosity and SVI oflow viscosity rubber at various treatment

\begin{tabular}{|c|c|c|}
\hline \multirow{2}{*}{$\begin{array}{l}\text { Jenis bahan aditif } \\
\text { Additive type }\end{array}$} & \multicolumn{2}{|c|}{$\begin{array}{l}\text { Parameter mutu } \\
\text { Quality parameters }\end{array}$} \\
\hline & $\begin{array}{l}\mathrm{M}_{\mathrm{V}} \\
M_{V}\end{array}$ & $\begin{array}{l}\text { SVI } \\
\text { SVI }\end{array}$ \\
\hline $\begin{array}{l}\text { Ammonium sulfat } \\
\text { Ammonium sulphate }\end{array}$ & $64 \mathrm{a}$ & $5 \mathrm{a}$ \\
\hline $\begin{array}{l}\text { Ammonium klorida } \\
\text { Ammonium chloride }\end{array}$ & $69 \mathrm{a}$ & $1 \mathrm{a}$ \\
\hline $\begin{array}{l}\text { Ammonium asetat } \\
\text { Ammonium acetate }\end{array}$ & $67 \mathrm{a}$ & $4 a$ \\
\hline $\begin{array}{l}\text { Ammonium dihidrogen fosfat } \\
\text { Ammonium dihydrogen phosphate }\end{array}$ & $64 \mathrm{a}$ & $4 a$ \\
\hline $\begin{array}{l}\text { Ammonium nitrat } \\
\text { Ammonium nitrate }\end{array}$ & $69 \mathrm{a}$ & $2 \mathrm{a}$ \\
\hline $\begin{array}{l}\text { HNS } \\
H N S\end{array}$ & $60 \mathrm{a}$ & $3 a$ \\
\hline $\begin{array}{l}\text { Blanko } \\
\text { Blank }\end{array}$ & $67 \mathrm{a}$ & $2 a$ \\
\hline
\end{tabular}

Keterangan : Angka yang diikuti huruf yang sama pada kolom dan baris yang sama, menunjukkan tidak berbeda nyata pada tingkat signifikasi $5 \%$ menurut uji jarak berganda Duncan

Note : Number followed by the same letter on the same line were not significantly with Duncan multiple range test at 5\%

mempercepat waktu yang berdampak pada peningkatan efisiensi konsumsi energi. Oleh karena itu penggunaan karet spesifikasi khusus seperti karet LoV lebih cenderung disukai pabrik ban.

Selain itu, penggunaan karet LoV diduga juga dapat mengurangi penggunaan bahan pelunak (plasticizer) dalam pembuatan kompon karet. Puspitasari dan Cifriadi (2014) menyatakan bahwa penggunaan bahan pelunak yang menyebabkan terputusnya rantai molekul karet mengakibatkan viskositas karet menjadi rendah. Besarnya penurunan viskositas karet sangat bergantung pada dosis penambahan bahan pelunak. Tujuan menurunkan viskositas karet alam dalam pembuatan kompon dengan menggunakan bahan pelunak dapat diminimalisasi dengan penggunaan bahan baku berupa karet LoV.

\section{Kadar Abu}

Hasil analisis kadar abu karet viskositas rendah (LoV) menggunakan berbagai aditif ditampilkan pada Gambar 2 . Penggunaan aditif berpengaruh terhadap kadar abu LoV yang dihasilkan. Kadar abu karet LoV dengan bahan aditif berupa ammonium sulfat, ammonium klorida, ammonium dihidrogen fosfat dan HNS (aditif kontrol) memenuhi persyaratan mutu ekspor berdasarkan SNI No.1903-2011. Persyaratan mutu untuk parameter kadar abu yang tercantum dalam SNI sebagai karet LoV adalah maksimum 0,5\%. Kadar abu karet viskositas rendah dengan bahan pemantap ammonium sulfat, ammonium klorida, ammonium dihidrogen fosfat dan HNS berturut-turut $0,50 \%, 0,49 \%, 0,49 \%$, dan $0,48 \%$.

Karet alam yang menggunakan bahan aditif ammonium asetat dan ammonium nitrat tidak memenuhi persyaratan mutu ekspor karet LoV sama seperti karet tanpa penambahan aditif (blanko). Hal ini dapat dilihat pada Gambar 2 dimana grafik kadar abu ammonium asetat $(0,98 \%)$, ammonium nitrat $(0,90 \%)$ dan blanko $(0,53 \%)$ berada di atas syarat maksimum mutu untuk karet LoV. Dengan demikian berarti bahan aditif berupa ammonium asetat dan ammonium nitrat tidak dapat digunakan untuk memproduksi karet LoV. Kadar abu yang tinggi dalam karet mentah akan mempengaruhi sifat dinamika alam seperti kalor timbul (heat build up) dan ketahanan retak lentur (flex cracking 


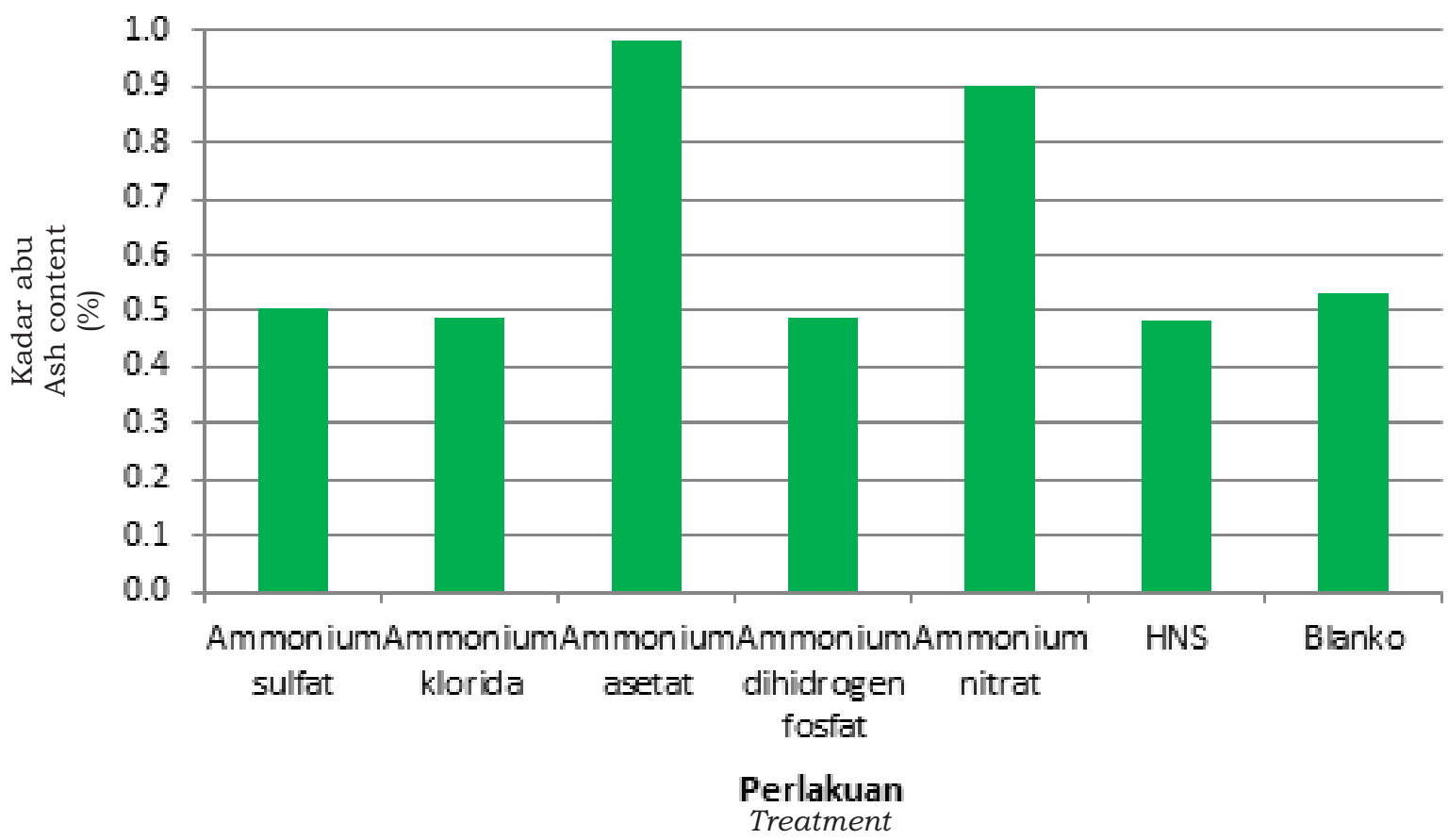

Gambar 2. Kadar abu karet viskositas rendah menggunakan berbagai aditif Figure 2. Ash content of low viscosity rubber using various additives

resistance) (Departemen Perdagangan dan Koperasi, 1981). Oleh karena itulah karet alam berkualitas harus memiliki kadar abu rendah sesuai yang tercantum dalam SNI No.1903:2011.

\section{Kadar Gel}

Perlakuan penggunaan aditif garam ammonium dalam pengolahan karet alam berpengaruh terhadap kadar gel. Berdasarkan Gambar 3 diketahui bahwa kadar gel karet viskositas rendah dengan aditif berupa ammonium sulfat, ammonium klorida, ammonium dihidrogen fosfat dan HNS (aditif kontrol) memenuhi persyaratan mutu berdasarkan SNI No.1903-2011 sama seperti karet tanpa penambahan aditif (blanko). Persyaratan mutu karet alam seperti tercantum pada SNI yang dapat dikategorikan ke dalam karet LoV seperti tercantum pada SNI harus mempunyai kadar gel maksimum 4\%.
Karet alam yang menggunakan aditif ammonium asetat dan ammonium nitrat tidak memenuhi persyaratan mutu sebagai karet viskositas rendah. Kadar gel masingmasing aditif tersebut berturut-turut 5,45\% dan $6,36 \%$. Tingginya kadar gel pada kedua karet LoV ini disebabkan banyak rantai molekul karet alam yang telah mengalami percabangan dan membentuk jaringan tiga dimensi, yang dicerminkan tingginya kadar gel dan nilai viskositas Mooney (Suparto et al., 2009). Penggunaan aditif berupa ammonium sulfat, ammonium klorida dan ammonium dihidrogen fosfat dapat menghasilkan karet alam dengan kadar gel rendah yang memenuhi standar mutu sebagai karet LoV. Murtanto (2003) menyatakan bahwa ban dengan kualitas yang baik seperti ban radial membutuhkan bahan baku karet yang berkualitas baik, yaitu karet alam yang mempunyai bobot molekul tinggi dan kandungan gel yang rendah. 


\section{KESIMPULAN DAN SARAN}

Hasil penelitian menunjukkan bahwa hanya dua jenis senyawa garam ammonium yang dapat digunakan sebagai aditif untuk menghasilkan karet viskositas rendah (LoV rubber), yaitu ammonium sulfat dan ammonium dihidrogen fosfat. Mutu karet alam yang menggunakan kedua aditif memenuhi persyaratan sebagai karet LoV sesuai dengan SNI No.1903-2011 tentang Standard Indonesian Rubber (SIR).

Penggunaan aditif ammonium sulfat dan ammonium dihidrogen fosfat sebesar $0,15 \% \mathrm{~b} / \mathrm{b}$ karet kering aditif dapat menghasilkan karet LoV dengan mutu berturut-turut yaitu plastisitas awal 34 dan 32; PRI 86 dan 83; viskositas Mooney 65 dan 65; SVI 5 dan 4; kadar abu 0,50\% dan 0,49\%; serta kadar gel 3,64\% dan 2,73\%.

Untuk mendapatkan hasil yang optimum dalam penggunaan ammonium sulfat dan ammonium dihidrogen fosfat sebagai aditif pembuatan karet LoV perlu dilakukan penelitian lebih lanjut termasuk perhitungan ekonomis yang kaitannya dengan biaya produksi dan aplikasi di tingkat pabrik.

\section{DAFTAR PUSTAKA}

Abednego, J. G. 1981. Pengetahuan Lateks. Dalam Departemen Perdagangan dan Koperasi. Kursus Pengawas 
Departemen Perdagangan dan Koperasi. 1981. Metode Pengujian Standard Indonesian Rubber (SIR). Kursus Pengawasan Mutu SIR. Direktorat Standarisasi, Normalisasi dan Pengendalian Mutu. Depdagkop, Jakarta.

Maspanger, D. R. 2008. Sifat Fisik Karet Dalam Balai Penelitian Teknologi Karet. Makalah Kursus Teknologi Barang Jadi Karet. BPTK, Bogor,: $75-$ 76.

Murtanto, H. H. 2003. Studi Penurunan Kandungan Gel pada Pengolahan RSS. Fakultas Teknologi Pertanian. Institut Pertanian Bogor, Bogor.

Puspitasari, S. dan A. Cifriadi. 2014. Karakterisasi Minyak Jarak Terhidrogenasi Sebagai Bahan Pelunak Karet Alami. Jurnal Penelitian Karet 32(1): $65-73$.

Solichin, M. 1991. Faktor-Faktor yang mempengaruhi Viskositas Mooney Dalam Pengolahan SIR 3 CV. Lateks. Pusat Penelitian Perkebunan Sembawa, Palembang.
Solichin, M. 1995. Pemantapan Viskositas Mooney Karet Alam dengan Natrium Fenolat, Natrium Metabisulfit dan Asetaldehida. Tesis Program Studi Teknologi Hasil Perkebunan. Program Pasca Sarjana Universitas Gadjah Mada, Yogyakarta.

Solichin, M dan V. Immanuel. 1991. Kajian Pembuatan Sit Angin yang Viskositasnya Dimantapkan. Buletin Perkaretan Vol.7, No.2, 94-100.

Solichin, M. dan T. Setiadi. 1992. Pengaruh Penambahan Hidroksilamin Netral Sulfat dan Lama Pemeraman Terhadap Mutu Lum Mangkok. Buletin Perkaretan 8(1): 17 - 25.

Suparto, D., Y. Syamsu., A. Cifriadi., dan S. Honggokusumo. 2009. Sifat Teknis Karet Remah dengan Viskositas Mooney dan Kadar Gel Rendah. Prosiding Lokakarya Pemuliaan Tanaman Karet 2009. Batam, 4 - 6 Agustus. Pusat Penelitian Karet.: 368 373. 